\title{
TRANSFER OF GERMAN MILITARY KNOW-HOW AND TECHNOLOGY TO THE OTTOMAN MILITARY FACTORIES AT THE BEGINNING OF THE FIRST WORLD WAR
}

\author{
ABDURRAHIM AYDIN* - TUNGAY ZORLU*
}

Throughout the Ottoman history, foreign technical missions and individuals found employment in various forms. It can be argued that the transfer of new technologies, sciences and concepts to the Ottoman Empire was to a great extent instrumental and oriented mostly toward solving immediate problems. Particularly, in such fields as military technology, firearms, mining, cartography, compasses and clock making, the Ottomans had a tendency to adopt and apply new developments efficiently without much time lapse through following technological developments by means of commissioning Ottoman ambassadors, technicians and other such travelers to observe and report what they saw abroad, and demanding technical missions from foreign countries to apply the new technology in the Ottoman lands and to educate Muslim technicians. ${ }^{1}$

From the late eighteenth century onwards Ottoman lands came to be a center of attraction for foreign technicians. Especially Selim III's cunning international policy, his diplomatic and political maneuvers were so successful that beside the technical missions who came through official channels, there were individual men, groups or families, who applied to the Porte on their own for possible technical jobs². Naturally, high wages were very influential in their employment as well. It was a fact that high quality foreign officers and engineers were paid much more than the Ottoman subjects and what they would have

*Yrd. Doç. Dr., İnönü Üniversitesi, İktisadi ve İdari Bilimler Fakültesi, İktisat Bölümü, Malatya/ TÜRKIYE, abdurrahimaydin@gmail.com

${ }^{* *}$ Prof. Dr., İstanbul Teknik Üniversitesi, Fen-Edebiyat Fakültesi, İnsan ve Toplum Bilimleri Bölümü, İstanbul/TÜRKIYYE, zorlu@itu.edu.tr

${ }^{1}$ Ekmeleddin İhsanoğlu, "Ottoman Science in the Classical Period and Early Contacts with European Science and Technology", Transfer of Modern Science and Technology to the Muslim World, IRCICA, İstanbul, 1992, pp. 1-49.

${ }^{2}$ Stanford Shaw, Between Old and New, Ottoman Empire under Selim III (1789-1807) (CambridgeMassachusetts, 1971), p. 141. 
had at similar jobs in their own countries. This enabled the Porte to choose from a wide spectrum of foreign missions through tests and examinations. Beside high wages, civil war, political turmoil, chaos or instability were among the driving factors for the foreigners to leave their countries to look for proper positions on the Ottoman territories ${ }^{3}$.

Foreigners who applied for suitable positions in Ottoman Empire varied in terms of their expertise, employment fields, methods of procurement and nationalities. They were mostly of engineers, technicians, architects, officers, physicians-surgeons, and workers, who were generally employed in naval arsenals, ports, barracks, cannon and gunpowder factories, forts and hospitals. The most common and influential means for their procurement were the Ottoman embassies abroad, the foreign ambassadors in İstanbul or high ranking statemen on both sides. In addition to these formal ways, there were informal applications including escapees, prisoners, refugees and individual workers. As for their nationalities, they were mainly of French, English, Scotch, Swedish, Austrian, Prussian, Spanish, Italian, Russian and Polish ${ }^{4}$.

These foreign experts rendered substantial contributions in the sphere of military and naval warfare including tactics, maneuvers and the use of navigational instruments. Shipbuilding, ship launching methods, construction of drydocks, production and use of new raw materials, tools and equipment were also among the sector they contributed to a great extent.

The final and probably most influential contribution was their training of Ottoman engineers and officers. They taught Ottoman students the above-mentioned branches in theoretical and practical courses organized within the body of the Naval and Land Engineering Schools. Additionally, other Ottoman subjects and artisans were given the opportunity to learn the intricacies of their arts in master-apprentice arrangements.

Thanks to their willingness to keep abreast of the latest developments in Europe and apply them to the various domestic sectors, the Ottomans maintained their politicaleconomic independence and self-sufficiency in many fields to a large extent. Strong central administration and policy of balance in international scale was also influential in this respect.

Although the Ottoman Empire was, to a great extent, self-sufficient in weapons industry at the turn of the $19^{\text {th }}$ century, it came to be completely dependent on foreign sources due mostly to the technological developments in defense sector in Europe. Technological dependence and its financial burden naturally paved the way for European

${ }^{3}$ Tuncay Zorlu, Innovation and Empire in Turkey: Sultan Selim III and Modernisation of the Ottoman Navy, IB Tauris, London\&New York, 2011, pp. 77-98.

${ }^{4}$ Kemal Beydilli, Türk Bilim ve Matbaacılk Tarihinde Mühendishane, Mühendishane Matbaast ve Kütüphanesi 1776-1826 (İstanbul: Eren, 1995), p. 85. 
countries to enter the Ottoman markets gradually. In spite of the fact that Germany was not the provider of the most competitive prices or the best quality products in comparison to the other countries, it was the leading country to have the greatest share in the weapons sector on the eve of WWI, because mostly of favorable political and commercial relations between two countries. Developments in Germany contributed to this favorable atmosphere as well. The unification of Germany, the rise of Wilhelm II as its emperor, and growing German economy in search of new markets and raw materials were significant factors. Wilhelm II's two subsequent visits to Istanbul in 1889 and 1898 respectively helped this process from a political aspect. Germany succeeded to obtain some concessions from Ottoman government as it is seen in the cases of Deutsche Bank, Izmit-Ankara, Anatolian and later Bagdad railways. On the other hand, Germany's supply of a state loan to the Ottoman Empire in 1910 was also an important gesture for the Ottoman side. As a result of all these developments, the years 1890-1910 witnessed almost threefold increase in Germany's impact on the Ottoman markets ${ }^{5}$.

As of the military aspects of the relations between the two countries, OttomanGerman Defense Alliance of 1790, Selim III's demand for military officials including the missions under Colmar von der Goltz in 1798, H. von Moltke in 1836 and Kaehler in 1882 to inspect the Ottoman army constituted milestones in the reformation of the Ottoman military. These military reforms strengthened and perpetuated the economic relations as well. Towards the end of the $19^{\text {th }}$ century German Krupp and Mauser companies monopolized Ottoman cannon and rifle markets ${ }^{6}$.

Soon it became Germany's strategy to penetrate in the Ottoman military market in order to secure economic and political interests against rival countries as well as to

${ }^{5}$ İlber Ortaylı, Osmanl İmparatorluğu'nda Alman Nüfuzu (German Influence in the Ottoman Empire), Timaş, İstanbul, 2012, pp. 47-69; Naci Yorulmaz, 'Ottoman Empire and Germany (1871-1908): Militaryeconomic Relationship, Trades Activities of German Armament Industry in the Ottoman Market', pp. 1-19; Arming the Sultan: German Arms Trade and Personal Diplomacy in the Ottoman Empire Before World War I, I.B. Tauris, London\&New York 2014.

${ }^{6}$ Mehmet Beşirli, 'Birinci Dünya Savaşı Öncesinde Türk Ordusunun Top Mühimmatı Alımında Pazar Mücadelesi: Alman Friedrich Krupp Firması ve Rakipleri (Struggle for the Market of Turkish Army's Purchase of Cannon Ammunitions during the Pre-WWI Period: German Friedrich Krupp Company and Its Rivals)', Selçuk Üniversitesi Türkiyat Araştırmalan Merkezi Dergisi, no. 15, Konya: Bahar 2004, pp. 169-203; Mehmet Beşirli, 'II. Abdülhamid Döneminde Osmanlı Ordusunda Alman Silahları (German Weapons in the Ottoman Army in the Reign of Abdulhamid II)', Erciyes Üniversitesi Sosyal Bilimler Enstitiusü Dergisi, no. 16, Year 2004/1, pp. 121-139; Fahri Türk, Türkiye ile Almanya Arasindaki Silah Ticareti 1871-1914 (Weapons Trade between Turkey and Germany 1871-1914), IQ Kültür Sanat Yayıncılık, Istanbul, 2012; Veli Y1lmaz, 1'inci Dünya Harbi'nde Türk-Alman Ittifakı ve Askeri Yardımlar (Turkish-German Allience in the WWI and Military Aids), Cem Ofset, İstanbul, 1993, p. 44-45; Jehuda L. Wallach, Bir Askeri Yardrmm Anatomisi: Türkiye'de PrusyaAlman Askeri Heyetleri 1835-1919 (An Anatomy of an Aid: Prussian-German Military Commitees 18351919), Translated by Fahri Çeliker, Genelkurmay Basımevi, $2^{\text {nd }}$ Issue, Ankara 1985. 
create new employment fields for its growing population. Some writers tend to explain Germany's penetration into the Ottoman market in terms of 'Germany's imperialism'. For instance, Illich goes further to claim that if the economic, political, military, educational, and cultural activities of the Germans in the Ottoman Empire are taken into consideration it is evident that the Ottoman Empire must be regarded in the historiography of German expansionism. He adds that while expanding into the Ottoman Empire, the Germans followed the British model used for the Middle East. However, this penetration model was not militaristic or even aggressive in comparison with the British or the French. Therefore, German expansion into the Ottoman Empire addresses the question of German exceptionalism as well ${ }^{7}$.

Despite increasing political and economic relations from the late $18^{\text {th }}$ century, basic factor to bring German and Ottoman interests together on the eve of WWI was their consideration of Russia as a common historical enemy. Therefore, previous German missions and services in the Ottoman army were not so decisive in the establishment of the German-Ottoman alliance in $\mathrm{WWI}^{8}$.

\section{German Know-How and Ottoman Military Factories}

With the onset of the WWI, German influence began to be felt in every walks of military technology and the production of weapons in particular. Establishment of new weapon factories or reconstruction of the old ones was a crucial need for the Ottoman authorities during the war years. Germany, as an ally of the Ottoman Empire, seemed the country where the technology and know-how was imported.

The case of Beykoz Debbağ ve Kundura Fabrikalan (Beykoz Tanners and Shoe Factories) constitutes a good example for the researches to follow the Ottomans use of German expertise to establish military factories in Istanbul. At first sight, these Beykoz factories seem to have nothing to do with the Ottoman army. However, they procured uniforms, boots and all the by-products of leather industry needed by the army.

It is possible to follow the developments of these factories through the activities of the Levazımat-ı Umumiye Dairesi (General Supplies Department) which operated under the Harbiye Nezareti (Ministry of War). Correspondences between this department with various military units shed light on the machinery of the process in question. For instance, the Dördüncü Şube (Fourth Branch) attached to the General Supplies Department sends an

${ }^{7}$ Illich, Niles Stefan, 'German Imperialism in the Ottoman Empire: A Comparative Study', PhD. Dissertation in History, Texas A\&M University, 2007; Malte, Fuhrman, 'Visions of Germany in Turkey: Legitimizing German Imperialist Penetrations of the Ottoman Empire', Free University, Berlin (undated), pp. 1-20.

${ }^{8}$ Edip Öncü, 'The Beginnings of Ottoman-German Partnership: Diplomatic and Military Relations Between Germany and the Ottoman Empire Before the First World War', MA Thesis in History, Bilkent University, Ankara 2003, p. 103. 
important letter (1332/1916) to various authorities. It mainly focuses on the need to make a deal with German Behstein ${ }^{9}$ Pirol Construction Company for the construction of Beykoz Debbağ ve Kundura Fabrikalan (Beykoz Tanners and Shoe Factories) as well as to meet the needs of such departments as Kireçhane (Limehouse), Debbă̆hane (Tannery), Perdahthane (Polishing House), Makine Dairesi (Engine Room), and Kimyahane (Chemical Process Works $)^{10}$. A contract is signed between two sides for this purpose. As of the contract, the German company agrees to provide the Turkish side with iron from the town of Rusçuk (Rousse) for the production of water and knee pipes, since 578 pipes in the stores were previously used and only 169 water pipes and four knees there left ${ }^{11}$. This example gives an idea what materials or equipment was demanded by the Ottomans.

It seems that some technical problems come out during the construction, repair and conversion operations as well as the adaptation of new import equipment. For instance, during a conversion process, four steam boilers are removed from Paper factory to be used as gas tanks and Kaymakam Sabri Bey is informed by the experts. However, during a water test conducted on 12 October 1916, there appear some leakages out of the nail heads, which requires caulking. There is nothing to do except to wait since the only expert Yusuf Efendi went to Istanbul in order to buy nails ${ }^{12}$.

Probably the most frequently mentioned factory construction by the archival documents is of Beykoz Debbağhanesi (Beykoz Tannery). In the following table (28 October 1918) prepared by Beykoz Factory construction officer, it is possible to find the amount and price of some materials such as iron, sand and gravel to be used in the construction. Moreover, the extent of excavation works for engine room, underwater excavations, layers, cement, cement plaster, isolation materials, tar and gravel layers are also given along with their quantitative and qualitative properties. Leather store within the construction is taken up under a separate heading and, its features such as reinforced concrete, steps, stair bars and inner-outer plaster are also explained in detail. Information concerning the Kimyahane (Chemical Process House) is also held under an independent title while daily wages of engineers, masons, ironsmiths, sergeants, soldiers and translators are grouped under daily allotment of military staff ${ }^{13}$.

${ }^{9}$ This word appears as 'Behştayn' or 'Bahştayn' in diffirent places in the archival documents we made use of.

${ }^{10}$ Genel Kurmay Askeri Tarih ve Stratejik Etüt Başkanlı̆̆ı Arşivi (General Staff, Military History and Strategic Studies Presidency Archives, ATASE), BDH-2093-23-001-02, BDH-2093-23-001-03, BDH-2093-23-00104.

${ }^{11}$ ATASE, BDH-2093-23-001-79.

${ }^{12}$ ATASE, BDH-2093-23-001-82.

${ }^{13}$ ATASE, BDH-2093-23-001-118. 
Beykoz Debbağhanesi Inşaatı (The Construction of Beykoz Tannery) (The Situation between 12-30 Kanun-ı Sani/January 1918)

\begin{tabular}{|l|l|l|c|}
\hline \multicolumn{1}{|c|}{ Quantity } & \multicolumn{1}{|c|}{ Material } & \multicolumn{1}{c|}{ Price per unit } & Total (qurush) \\
\hline 15,5 tons & Round iron & 1 ton $=2200$ qurush & $33.110,00$ \\
\hline 520,00 tons & Sand and gravel & $2 \mathrm{~m}^{3}=40$ qurush & $20.800,00$ \\
\hline 90 rolls & Bitumen felt (Ruberoit) & 1 roll $=220$ qurush & $19.800,00$ \\
\hline
\end{tabular}

Makine Dairesi (Engine Room)

\begin{tabular}{|c|c|c|c|c|}
\hline Quantity & Unit & Operation and Materials & $\begin{array}{l}\text { Price per } \\
\text { unit }\end{array}$ & Total \\
\hline 61,03 & $2 \mathrm{~m}^{3}$ & Excavation on rock ( $2 \mathrm{~m}$ depth) & $2 \mathrm{~m}^{3}=25$ & $1.525,75$ \\
\hline 430,79 & $2 \mathrm{~m}^{3}$ & Excavation on rock (2-3m depth) & $2 \mathrm{~m}^{3}=30$ & $12.923,70$ \\
\hline 143,01 & $2 \mathrm{~m}^{3}$ & Excavation on rock (3-4m depth) & $2 \mathrm{~m}^{3}=35$ & $5.005,35$ \\
\hline 85,71 & $2 \mathrm{~m}^{3}$ & Excavation on rock (4-5m depth) & $2 \mathrm{~m}^{3}=40$ & $3.428,40$ \\
\hline 36,64 & $2 \mathrm{~m}^{3}$ & Excavation on rock (5-6m depth) & $2 \mathrm{~m}^{3}=45$ & $1.648,40$ \\
\hline 696,15 & $2 \mathrm{~m}^{3}$ & Stone for underwater excavation & $2 \mathrm{~m}^{3}=7$ & $4.873,05$ \\
\hline 531,88 & $2 \mathrm{~m}^{3}$ & Ordinary cement & $2 \mathrm{~m}^{3}=250$ & $132.970,00$ \\
\hline 104,64 & $2 \mathrm{~m}^{3}$ & Isolation layer & $2 \mathrm{~m}^{2}=35$ & $3.662,40$ \\
\hline 58,80 & $2 \mathrm{~m}^{2}$ & Tar layer & $2 \mathrm{~m}^{2}=35$ & $2.058,00$ \\
\hline 58,80 & $2 \mathrm{~m}^{2}$ & $\begin{array}{l}\text { Cement coat (700 kg of cement } \\
\left.\text { for } 0,2 \mathrm{~m}^{3}\right)\end{array}$ & $2 \mathrm{~m}^{2}=25$ & $1.470,00$ \\
\hline 47,64 & $2 \mathrm{~m}^{3}$ & Gravel layer & $2 \mathrm{~m}^{3}=40$ & $1.905,60$ \\
\hline $1.274,03$ & $2 \mathrm{~m}^{2}$ & Timber mold & $2 \mathrm{~m}^{3}=25$ & $31.850,75$ \\
\hline & & & & $\begin{array}{r}203.321,40 \\
\text { (qurush) }\end{array}$ \\
\hline
\end{tabular}

Deri Ambarn (Leather Store)

\begin{tabular}{|r|c|l|l|r|}
\hline Quantity & Unit & \multicolumn{1}{|c|}{ Material } & \multicolumn{1}{c|}{ Price per unit } & Total Price \\
\hline 15,27 & $2 \mathrm{~m}^{3}$ & Reinforced concrete & $2 \mathrm{~m}^{3}=570$ qurush & $8.703,90$ \\
\hline 47,60 & 2 tons & Stair & 2 tul $=115$ qurush & $5.474,00$ \\
\hline 206,98 & $2 \mathrm{~m}^{2}$ & Timber mold & $2 \mathrm{~m}^{3}=25$ qurush & $5.174,50$ \\
\hline 76,50 & Kilo & Stair irons & 6 qurush per kilo & 459,00 \\
\hline 4,60 & $2 \mathrm{~m}^{3}$ & Reinforced concrete & $\begin{array}{l}2 \mathrm{~m}^{3}=570 \\
\text { qurush }\end{array}$ & $2.622,00$ \\
\hline
\end{tabular}




\begin{tabular}{|c|c|c|c|c|}
\hline $1.433,79$ & Kilo & $\begin{array}{l}\text { More than } 60 \mathrm{~kg} \text { iron per } \\
2 \mathrm{~m}^{3} \text { reinforced concrete }\end{array}$ & 3 qurush per kilo & $4.301,00$ \\
\hline 3,33 & $2 \mathrm{~m}^{3}$ & Brick wall & $2 \mathrm{~m}^{3}=275$ qurush & 915,75 \\
\hline \multirow[t]{2}{*}{11,05} & $2 \mathrm{~m}^{2}$ & Plaster for outer façade & $2 \mathrm{~m}^{2}=25$ qurush & 276,25 \\
\hline & & & & $\begin{array}{r}294.958,57 \\
\text { ( qurush) } \\
\end{array}$ \\
\hline 11,05 & $2 \mathrm{~m}^{2}$ & Internal plaster/coating & $2 \mathrm{~m}^{2}=12$ qurush & 132,60 \\
\hline$* * *$ In & dan & $\begin{array}{l}\text { h the price chart accep } \\
d 1 / 9 / 1317 \text { (14 Novem }\end{array}$ & y Ministry of Wa & $\begin{array}{l}\text { correspon- } \\
587 / 2915\end{array}$ \\
\hline
\end{tabular}

Kimyahane (Chemical Process House)

\begin{tabular}{|c|c|c|c|c|}
\hline Quantity & Unit & $\begin{array}{l}\text { Operation and } \\
\text { Materials }\end{array}$ & Price per unit & $\begin{array}{l}\text { TOTAL } \\
\text { PRICE }\end{array}$ \\
\hline 29,33 & $2 \mathrm{~m}^{3}$ & Excavation (2m depth) & $2 \mathrm{~m}^{3}=25$ qurush & 733,25 \\
\hline 10,57 & $2 \mathrm{~m}^{3}$ & Excavation (2-3m depth) & $2 \mathrm{~m}^{3}=30$ & 317,10 \\
\hline 29,98 & $2 \mathrm{~m}^{3}$ & $\begin{array}{l}\text { Excavation (beside one } \\
\text { under the water) }\end{array}$ & $2 \mathrm{~m}^{3}=7$ & 209,86 \\
\hline 12,56 & $2 \mathrm{~m}^{3}$ & $\begin{array}{l}\text { Usual Cement (for chan- } \\
\text { nel) }\end{array}$ & $2 \mathrm{~m}^{3}=275$ & $3.454,00$ \\
\hline 31,08 & $2 \mathrm{~m}^{2}$ & $\begin{array}{l}\text { Cement coating (with } \\
700 \mathrm{~kg} \text { cement for } 2 \mathrm{~m}^{3} \\
\text { sand) }\end{array}$ & $2 \mathrm{~m}^{2}=25$ & 777,00 \\
\hline 31,08 & $2 \mathrm{~m}^{2}$ & Tar coating & $2 \mathrm{~m}^{2}=3$ & $1.087,80$ \\
\hline 20,80 & $2 \mathrm{~m}^{2}$ & $\begin{array}{l}\text { Cement coating (with } \\
700 \mathrm{~kg} \text { cement for } 2 \mathrm{~m}^{3} \\
\text { sand) }\end{array}$ & $2 \mathrm{~m}^{2}=25$ & 520,00 \\
\hline 39,18 & $2 \mathrm{~m}^{2}$ & Timber mold & $2 \mathrm{~m}^{2}=2$ & 979,50 \\
\hline 252,59 & Kilo & Stair rail & 6 qurush per kilo & $1.515,54$ \\
\hline $15.050,00$ & Kilo & Repair of round irons & $\begin{array}{l}367 \text { qurush for } 100 \\
\text { kilo }\end{array}$ & $55.233,50$ \\
\hline \multicolumn{5}{|c|}{$\begin{array}{l}\text { ***In accordance with Ministry of War's correspondence dated 2/4/1334 (2 June } \\
\text { 1918) and numbered 51/1055 }\end{array}$} \\
\hline \multicolumn{3}{|c|}{ Combined Total } & \multicolumn{2}{|c|}{ 369.918,72 qurush } \\
\hline
\end{tabular}


Asker Yevmiyesi (Daily Wages for Soldiers)

\begin{tabular}{|l|c|c|c|}
\hline Profession & Days & Wage per day & Total Wages \\
\hline Engineer & 21 days & 60 qurush & 1.260 qurush \\
\hline Mason & 122 & & \\
\hline Carpenter & 127,5 & & \\
\hline Ironsmith & 21 & & $\mathbf{6 . 7 6 2 , 5 0}$ qurush \\
\hline & $\mathbf{2 7 0 , 5}$ (total) & $\mathbf{2 5}$ qurush & \\
\hline Sergeant & 21 & & \\
\hline Soldiers & 3145,5 & & $\mathbf{1 5 . 9 3 7 , 5 0}$ qurush \\
\hline Translator & 21 & & $\mathbf{2 3 . 9 6 0 , 0 0}$ qurush \\
\hline \multicolumn{4}{|r|}{} \\
\hline & $\mathbf{3 1 8 7 , 5}$ (total) & $\mathbf{5}$ qurush & \\
\hline
\end{tabular}

\begin{tabular}{|l|l|}
\hline EXPENSES & QURUSH \\
\hline Soldier's wages & $23.960,00$ \\
\hline Engine Room + Leather Store+Chemical Process House & $369.918,72$ \\
\hline OVERALL & $\mathbf{3 9 3 . 8 7 8 , 7 2}$ \\
\hline
\end{tabular}

It is understood from the above tables that the construction of Beykoz Debbağhanesi (Beykoz Tannery) is a process that requires the appointment of a construction officer, procurement of main construction materials, planning the excavation works for engine room, leather store, and chemical process house, as well as finding skilled engineers, masons, ironsmiths, sergeants, soldiers and translators. If we judge from the calculations by the construction official of the Beykoz Factory, this factory enterprise cost 393.878,72 qurush in total. When considered the exchange rates of the time (28 Teşrin-i Evvel 1334/28 October 1918), 1 Ottoman Lira equals to 21 Deutsche Mark and therefore, overall total is 77682 Mark 93 Pfennig. This exchange rate comparison shows clearly the German influence on the procurement of some construction materials and know-how as well ${ }^{14}$.

\section{Military Supplies Committees and Their Duties}

Both know-how and supply of the technical/military supplies was crucial business during the war years. Various contracts were made between Enver Pasha, the Minister of War (Harbiye Nazırı) and Tüfenkciyef, the engineer who lived in Sofia, concerning the military supplies. In such three contracts dated 19 February 1329 (4 March 1914), 30 May 1331 (12 June 1915) and 7 June 1331 (20 June 1915) respectively, the condition and

${ }^{14}$ ATASE, BDH-2093-23-001-118. 
prices of the supplies were determined. Delivery of 25.000 hand grenades (el humbarasi) to Istanbul within one and a half month from the time of the contract onwards and payment of these supplies on the time of delivery was demanded in a supplement to the contract on 7 June 1331 (20 June 1915). In addition to the empty hand grenades, globes, fuse, match cases (kibritlik), bombits and detonators (kapol) were demanded as well ${ }^{15}$.

It seems that existing committees were not sufficient to meet the need and new committees were established in order to speed up the exchange of military articles between Germany and Ottoman Empire. In a document dated 10/06/1333 (10 August 1917) and written by Laws and Regulations Department (Kavanin ve Nizamat Şubesi) which was attached to the Ministry of War (Harbiye Nezareti), implementation of certain articles were ordered in order that Berlin purchasing and delivery committee speed up and regulate its activities. There would be following additions to the staff of the Committee: a) three officers having a great command of German language (one from Ministry of War, one from General Supplies Department and the other from Military Production Department; b) two documentalists who can read and speak German (scribe/katip, officer/zabit or reserve officer/ihtiyat zabiti, deputy officer or educated officer/soldier of low rank); five clerks (educated private soldiers are also eligible); d) a German civil servant who would act under the documentalists and keep the register and files of correspondence and documents in German; e) a German civil servant who would work under accountants and, follow and see to the register and accounts in German; f) three German civil servants in charge of recording the communication in German and engrossing it through writing machines are needed immediately. Furthermore, the legal advisor (hukuk müşaviri) and the doctor who were already within the committee and familiar with German language would be appointed and commissioned as soon as possible for the same sake.

The commission of the aforementioned civil servants would be chosen from junior officers and among those who could carry out above-defined jobs. This task would be demanded from the Prussian Ministry of War. The Committee would be responsible for the preparation and examination of the employment lists, relevant documents, and correspondence concerning the commissioned officers; preparation of the contracts and orders; following up the entire process with the Prussian Ministry of War and with other bodies in question; examination of the depots, transfers and delivery; following the works of the civil servants and checking up the accounts, and correspondence. While carrying out all these duties there would be a division of labor in order to move fast and carefully, and an internal instructions chart would be prepared and presented to the Ministry of War to this end.

${ }^{15}$ ATASE, BDH-2098-2-001, BDH-2098-2-001-02. 
Committees were responsible for the wording of all the accounts, correspondences and lists in a planned, clear and well-classified form. For instance, goods and materials of different kind on the order lists would not be written on the same list. In contrast, they would be classified and written on separate lists based on their types. Proper technical information would be given about the system, dimension and similar properties of the materials.

The telegraphs and documents to be sent to the committee would not address to the name of the military attachés but to that of TeuaK Berlin, or the present address of the Berlin-Ottoman purchasing committee, 'TeuaK Berlin W. Augsburger Str. 45'. A special code/ cipher would be prepared and sent to the committee for the ciphered telegraphs.

Depending on the legal permission of the Ministry of War, some groups composed of experts would also be commissioned to work in compliance with the orders of the committee in order to check, control, follow, discuss and examine the special orders with higher significance on their sites ${ }^{16}$.

All these articles clearly show how much importance is attached to a proper communication between two parties by German and Ottoman sides. It is also understood that both sides considered all this purchase and delivery procedure to be an urgent need that should be met safely by the specialists without causing any damage.

\section{Domestic Supplies of Military Materials}

When the correspondence regarding the purchase of equipment from abroad continued on one hand, attempts concerning the effective use of the domestic resources were going on the other. In a draft document by the Translation Unit of General Military Supplies Department (Levazımat-1 Umumiye-i Askeriye Dairesi Mütercimliğine Mahsus Müsvedde), important information was transmitted about the sources of coal in Yalova and it is emphasized that works to be done in the coal mine would be beneficial. According to the report, 60-70 thousand tons of coal would be extracted through 300m-long channels in east-west direction by increasing the axles to two arşın, which were in 40-50m depth and 80-100m distance in the lode.

As for the transfer of the coal extracted, it was considered that a coal park would be created near macadamized road, from which wagons or cars would carry the coals to the Yalova port. However, the report also added that the type of the lode would not be assessed properly in the present stage. There was a considerable optimism for the extraction of the coal, which was probably, Linyit/Lignite/brown coal.

${ }^{16}$ ATASE, BDH-2103-15-001-41. 
During the feasibility works conducted by the chief engineer on 26 July 1915, it was predicted that 50 workmen and 20 mules would be needed in the first stage of extracting coal, starting with 10-15 tons in the first few days, and increasing it day by day to reach a power of 44-46 calories.

It was reported that they had better start with a depth of $10-15 \mathrm{~m}$, felling certain amount of trees for the construction of a few corridors with traverses. It was also mentioned that there was a need for 40-50 workmen for 20-25 tons of coal.

According to the plan, timber which was the most important and urgent need, would be procured from Yalova and its surrounding areas. Among other materials which had been ordered fifteen days ago were 2 manual windlasses, 2 crane machines, 100 couples of mine car wheels or 50 mine cars, rails of $500-600 \mathrm{~m}, 3$ crates of dynamites (along with hoods and fuses), $50 \mathrm{~kg}$ of steel (for drilling), 5 pieces of hammer (each $5-5.5 \mathrm{~kg}$ ), 5 pieces of mining shovel, 10 pieces of mining axes, 200 pieces of timber $(2-2.5 \mathrm{~cm} \text {-thick })^{17}$.

\section{Transfer of Military Supplies}

Transfer of military supplies was important issue in those years. In fact, just before the WWI, an agreement was made between Ottoman and German governments to this end. LTC Bischoff (Pisof), Major in German Army was commissioned during the Balkan Wars to reorganize the transportation system of the Ottoman Empire whose previous transportation system had been established during Ottoman-Russian War of 1877-1878 ${ }^{18}$.

Beside the materials to be used in the construction of military facilities, the production of the materials likely to be used by military units and their delivery from the production sites was also a matter of considerable significance. For instance, in a note written as a reply to the telegraph (19 March 1916) of the Daire-i Harbiye Riyaseti Vekalet-i Aliyyesi, some information is given about the materials belonging to the factories of military production in Ruşcuk, and methods of transferring them into Istanbul.

${ }^{17}$ ATASE, BDH-2103-16-001.

${ }^{18}$ Bülent Durgun, 'Alman Islah Heyetleri ve Bischoff'un Balkan Harbinde Osmanlı Ordusu'nun Ulaştırması Hakkında Değerlendirmeleri (The German Military Missions in Turkey and Evaluations of the Inspector Bischoff on the Transportation Issues in the Ottoman Army', Türk Dïnyast Incelemeleri Dergisi / Fournal of Turkish World Studies, XII/2 (Winter 2012), pp.101-120. 


\begin{tabular}{|c|l|}
\hline \multicolumn{2}{|c|}{ Military supplies in Rusçuk to be transferred to Istanbul } \\
\hline Wagon & \multicolumn{1}{c|}{ Quantity } \\
\hline 4 & 15.000 shrapnel steel \\
\hline 2 & 10.000 massive rifle barrel \\
\hline 19 & $\begin{array}{l}\text { Steel bars of various sizes and profiles, from the smallest one to the biggest } \\
\text { (circle, rectangular, and square) }\end{array}$ \\
\hline 1 & Steel sheet \\
\hline 20 & 22.000 zinc sheets (each with a surface of approximately $1.5 \mathrm{~m}$ ) \\
\hline 30 & $\begin{array}{l}\text { Refractory brick of various shape and size } \\
\text { (a sample of each of them has been sent to the Inspectorate of Weapons) }\end{array}$ \\
\hline 1 & Graphite pot (with various sizes) \\
\hline Source: ATASE, BDH-2120-41-004 \\
\hline
\end{tabular}

In order to transfer the above-mentioned military materials with specific amounts and properties to Istanbul, Rusçuk train administration prepared 40 cars a day for the Ottoman government: 38 out of them loaded with flour and crops for the General Military Supplies Department and two others loaded with military equipment. The properties of the military equipment to be loaded on these two cars would be demanded from the German Port Command in Rusçuk by Kaymakam Bey in Istanbul, and the cars in question would be loaded under the supervision of the German Port Command.

It was estimated that for the transfer of the above-mentioned materials to Istanbul, almost 77 cars would be needed. Therefore, a few additional cars out of 38 cars would be allotted to the shipment of the military supplies as well upon Kaymakam Bey's remarks ${ }^{19}$.

\section{Tophane Factories and Their Need for Foreign Military Supplies}

Tophane factories themselves manufactured some of the military supplies and purchased or provided others from abroad. They sometimes failed to meet demands. For instance, in a petition written by Tophane Fabrikalan Müdüriyyeti (The Directorate of Tophane Factories), the reason why the production of the demanded materials was impossible under ensuing conditions was cited:

1. Transformation and renovation activities in the factory buildings and workbenches required for the production of 'muaddel' (imitation) Mauser rifles in great quantities started on 21/01/1331 (3 April 1915) with an order numbered 62808. Since these workbenches were removed from their places, there would not be any production until these construction workbenches are completed. As the workbenches brought from Europe are not laid out yet, they could not be used as well.

${ }^{19}$ ATASE, BDH-2120-41-004. 
2. Transformation of the present workbenches which were adjusted for the production of 'muaddel' (imitation) Martini in $327 \mathrm{~m}$, into the ones suitable for the production of Mauser rifles are underway. Although Martini spare parts could be manufactured on these workbenches, other spare parts could not be produced at all. Therefore, some workbenches are out of use.

3. In addition, rifle factory carries out necessary renovations/repairs in the workbenches where orders for the daily production of the side arms and bayonets of ordinary and machine rifles are provided.

4. Factory renovation conducted for 'muaddel' (imitation) Mauser equipment and workbench transformation will take a long time. Even if they were completed, it would not be possible to produce spare parts for all the rifles. There is no difference between the production of spare parts and rifles. However, it is clear that all kinds of weapons could not be produced in a single factory. Mauser rifles with case and switch (Çantalı ve anahtarlı Mavzer tüfekleri) would not be manufactured as well in a factory whose workbenches were transformed into the ones suitable for similar 'muaddel' (imitation) Mauser ${ }^{20}$.

\section{Mauser Rifles and Weapons Factories}

There are many archival documents concerning the Mauser rifles, their ammunition and secondary equipment used in 1915-16. One of them involves information about the materials belonging to 57th, 71st and 79th machine guns divisions of 1st, 3rd and 5th Army Corps, 9th Squadron between January and March 1915. Among the secondary materials were 12 Hoçkis ammunition boxes, Hoçkis harness saddle, 120 chargers, 4 carpenter marapact; $24 \mathrm{~kg}$ mineral oil, 3 cans for mineral oil, 3 wooden boxes for mineral oil; and 50 revolvers of various types.

It is also understood from the document that among the materials belonging to the 5th Army Corps, the 45th regiment in the waybill numbered 577 and dated 3 March 1915, were 10 Mausers with switch bayonet mudguard and 20 ramrods for Mausers with switch. The document also mentions that there were 120 rifles that had stayed in Silahhane Rifle Factory for more than four months, before handed over to the military production unit in Silahhane one month ago: 100 'Muaddel' (imitation) Mauser rifles, 16 Mauser rifle with switch (anahtarl mavzer tüfegi), 1 big-size Mauser rifle,2 Mauser rifles with case (Çantah mavzer tüfeği), 1 small-size Martin rifle. These are reported to have belonged to $94^{\text {th }}$ and $96^{\text {th }}$ regiments, 32nd division ${ }^{21}$. All these materials and rifles are important to constitute an idea of the Ottomans' war supplies in the time.

\footnotetext{
${ }^{20}$ ATASE, BDH-2120-42-001-025.

${ }^{21}$ ATASE, BDH-2114-20-001-12.
} 
It is known that Ottoman-German weapons trade relations which started with Krupp Company went on with another German company in the late 19th century. Ottomans War Ministry signed an agreement on 9 February 1887 with Waffenfabrik Mauser Company for the supply of infantry rifles. According to the agreement this German company undertook the production and delivery of 500.000 'mükerrer atışlı' infantry rifles (with repetitive shooting) and 50.000 carbines (karabina) for the Ottoman army ${ }^{22}$.

It is interesting to note in the above-mentioned document that, beside the ones purchased from German companies there were also 'muaddel' or 'imitation' Mauser rifles produced by Tophane and Zeytinburnu Tüfekhanesi (Rifle Factory). The number of the 'muaddel' ones would reach significant numbers in the course of time, especially during the WWI and pave the way for the production of prospective domestic rifles ${ }^{23}$.

Military correspondence provides the researches with not only information about the weapons but also the wagons/cars used for the transportation of some military materials and equipment as well as field glasses (sahra dürbünü). For instance, payment was demanded for the expenses of the equipment of the transport cars which had been manufactured in Zeytinburnu Factory in a document (25 Şubat 1329/10 March 1914) written by Sahra Top̧̧u ve Nakliye Kitaatı Dairesi (Field Artillery and Transport Division) to Muhasebat Dairesi (Accountancy Department) ${ }^{24}$. Moreover, information was given about the battery telescope, 'batarya dürbünü' and the repair of its stillage in another letter dated 02/11/1331 (15January 1916) written by Kaymakam Bey, the Mevki-i Müstahkem Kumandan (Commander of the Fortified Site) in Anadolu Kavağ̣ Headquarters, to the Esliha Müfettiş- $i$ Umumiliğ $i$ (General Inspectorate of Weapons) ${ }^{25}$.

\section{Mr. Behstein's Proposals for the Rifle Factory}

Probably the most significant correspondence takes place between Mr. Behstein, the science director of the Loda Factory and General Directorate of the Military Manufacture (İmalat-1 Harbiye Müdüriyet-i Umumisi). Ottoman side demands Mr. Behstein to provide a report concerning the re-establishment, extension and improvement of the rifle production capacity of the present rifle factory. Behstein prepares a report based on his observations, researches and examinations. Contrary to the common belief, he suggests that this old factory in question is not capable of manufacturing a rifle of the latest technology. He adds that the problem is not only with the manufacturing workbenches but also with

\footnotetext{
${ }^{22}$ Ali Serdar Mete, Osmanl Imparatorluğundan Türkiye Cumhuriyetine Türk Ordusunda Mavzer Tüfekleri (Mauser Rifles in the Turkish Army from the Ottoman Empire to the Turkish Republic)', MA Thesis at the Institute of Ataturk's Principles and History of Turkish Renovation, Yeditepe University, 2012, p. 53.

${ }^{23}$ Ali Serdar Mete, Mavzer Tüfekleri, p. 175.

${ }^{24}$ ATASE, BDH-2133-1-001.

${ }^{25}$ ATASE, BDH-2346-39-001-08, BDH-2346-39-001-35, BDH-2346-39-001-57.
} 
appropriate assembly designs and controls. Then he gives elaborate information about the necessary construction and restitution work in order to make the factory operative with the latest technology. He enumerates a list of 'things to-do' within the building in order to obtain a factory capable of manufacturing 250 rifles through 20 hours of operation a day:

First of all, working areas should be well-lit. So, ceiling of the factory should be opened completely in order to better observe the possible problems and faults.

It is necessary to apply wooden furnishing to the working places where workbenches stand. Furnishing of $50 \mathrm{~mm}$ pine wood should be made and then another one should be prepared from hard wood on the first one. This system has been so beneficial for our factories which have been in operation since 1898, that we will use it same way for the new factories we are building now. We are ready to present you required construction pictures.

Moveable transmission mechanisms rotate rather slowly. With the help of the adoption of speed-cutting steel, rotation level can be increased to at least 150 and in some cases to 250 in a minute ${ }^{26}$.

These speed-rotating movement pins require the use of small-scale sledges, which in turn, enables the burden on them to ease. Large-scale sledges are already insufficient as well as they prevent the light coming from above to a large extent.

Machines that operate through power of movement are not enough for factories to operate perfectly and there will be a need for machines to operate by partial-electrical power. This, in turn, will make the use of many machine parts unnecessary. Hence, mounting electric engines of 15, 20 and $25 \mathrm{hp}$ to each part will be the best choice. So, the risk of being dependent on a single source of energy for all the operations in case of a problem will be eliminated.

He adds that, the present steam power would naturally be in use as well. However, 20 hours a day-work on an area of $3500 \mathrm{~m}^{2}$ in one of the old workshops would not suffice in order to manufacture 250 rifles which were demanded. For him the area in question only suffices for the settlement of workbenches which are needed to process iron and steel parts of rifles. There are no proper places for such places as Bilemehane (Sharpening Workshop) and Boyahane (Dyeing Workshop). He goes on suggesting that although these places are on the upper floor, it is not appropriate for them to stay there. In order to prevent them from dust and dirt which come out during work, they should be separated from each other and established in places away from the factory. For possible hitches, workbench tools-equipment and repair tools should be manufactured at first. The construction of such workshops should be started immediately, since there is a suitable space near the administrative/directorate building. It is possible to start to work without causing any problem to the present production.

${ }^{26}$ ATASE, BDH-2346-40-001-13. 
Mr. Behstein says that he explained his company's approach regarding the distribution of the places in an attached sketch. He also presents an additional plan including the space sketches of the bigger-size workbenches. When the construction of the new building was completed, workshops for workbench and repair tools would be moved to the place where present gunstock factory (kundak fabrikasi) stays ${ }^{27}$.

Mr. Behstein recommends that transferring the gunstock factory (kundak fabrikasi) into a new building should make it more operational. So, having all the branches of the rifle factory near to each other saves time required to convey various parts of rifles.

As far as Behstein report concerned, Ironworks (Demirhane) within Cannon factory needs to be left for Rifle factory. It is possible to produce hammer iron or steel through the press required for Cannon factory. However, the opposite is not possible. A fundamental plan would be made for hammers and furnaces. For the Annealing and Hardening workshops (Tavlama ve Sertleştirme Atölyesi) to work properly, present shooting gallery needs to be cancelled and buildings to be all repaired. He maintains that present Hardening workshop is in a state of complete useless. There isn't any crucial installment needed for an up-to-date Hardening workshop. In the attached report, he explains related basic installments. In the new polygon, shooting range would be arranged to allow $50 \mathrm{~m}$ in general and $150 \mathrm{~m}$ when needed. Certain number of rifles that need to shoot longer ranges would be transferred to more appropriate polygons without any hesitation

As for the sheds on the right of the entrance, Behstein says that they might be rearranged for the preservation of mount timbers, when the mount factory is moved to another building. He prepares a sketch which shows that a Drying Workshop (kurutmahane) is being established for mounts so that dried mounts can be transferred to the workshop immediately without being exposed to any outer influence. He further suggests that the installment required for the Mount Drying Workshop (Kundak Kurutmahanesi) would be presented in the bid in question. As for the workbenches, repair and field tools, the workbenches needed to produce 250 rifles in 20 hours a day are included in the bid mentioned. Some 185 workbenches which were previously ordered and those already present in the factory are taken into consideration. Mr. Behstein adds that determining the number of these last workbenches was naturally impossible due to his short stay there. However, 150 of them could be used. In any case, more workbenches need to be repaired and converted. However, exact number would be possible only after some examinations ${ }^{28}$.

If the connection fixings, repair tools, workman rulers (mistars), examiner rulers (mistars) are considered as before, he recommends the immediate procurement of one set of

\footnotetext{
${ }^{27}$ ATASE, BDH-2346-40-001-14.
}

${ }^{28}$ ATASE, BDH-2346-40-001-15. 
connection fixings, one set of cutting tools, one set of workman rulers, one set of examiner rulers. These items should be supplied simultaneously. Supply of workbenches only is not enough at all, since most of them were ordered without their repair tools. On the other hand, he says that mistars (rulers) were not ordered at all. Speeding up the delivery of the workbenches is useless, in case previously mentioned parts are not delivered. These are rather in the state of special manufacture and their production in large quantities is not possible there. He suggests that if the workbenches are repaired and workshop for repair tools are constructed after these repair tools are delivered by them, others could also be carried out by imitating them.

Mr. Behstein states that if his company is ordered to supply the workbenches which they proposed for this workshop according to the samples to be provided, they would first try hard to deliver spare repair tools in order to be able start their production in the rifle factory soon.

He warns that there are many other things to consider and to remember. However, if all the institutions his factory proposed are ordered to them, they would provide a complete and a more comprehensive plan. He finally suggests that if his remarks and proposals are accepted, his factory would present the personnel and teams required immediately to Ottoman service in order to complete this enlargement and rearrangement work (Istanbul 21 Teşrin-i Evvel/October 1915, Behstein, Deputy Director of the Loda Factory) ${ }^{29}$.

The responding letter dated 22/08/1331 (4 November 1915) written by the General Director of the Military Production (İmalat-1 Harbiye Genel Müdürü) suggests that the examinations conducted up to the time showed that the changes needed within the factory were not feasible. He adds that if the transfer and assembly of the workbenches were waited, this time would take at least one year. Within this short time, excellent rifles of factory production could not be possible and therefore their production would be postponed.

However, he states that when the additional time for the test period beside the time required for the order of workbenches, their conveyance, assembly and operation was taken into consideration, the tools and equipment needed should be ordered immediately along with workbenches in order not to lose any time.

The report also adds that Behstein Factory with its experience in Loda Factory would help the production process in the establishment of such a plant. After the establishment and successful operation of the factory, German technicians would hand it over to the Ottoman experts. The report includes the workbench list that was mentioned in the Behstein report as well ${ }^{30}$.

\footnotetext{
${ }^{29}$ ATASE, BDH-2346-40-001-16.

${ }^{30}$ ATASE, BDH-2346-40-001-22.
} 
The report also estimates that the war would probably continue one more year. Hence, the production of excellent rifles would be very difficult, if not impossible, when considered such needs as the repairs and reconstruction of the old buildings, supply and assembly of the workbenches, the production of devices and rulers. Therefore, proper planning and experienced masters would be needed.

The report also points out that new workbenches needed should not be supplied haphazardly as it was done in previous 180 workbenches and it should be ordered from Loda Factory, which was the expert in the field. In order to see if the construction of the required buildings, the assembly of the workbenches, completing some deficiencies, and putting the factory in a position to be able to produce 250 rifles in 20 hours, the factory should be operated and then handed over. The report goes on suggesting that if possible, old workbenches in the factory should be repaired, and converted. Meanwhile, assembly devices and rulers should be ordered from Loda Factory under the aforementioned plan. Therefore, there should be a team/committee that is responsible for the establishment and operation of the required institution. The report warns that, otherwise, if the method of supplying workbenches from different factories is adopted, the problem of strengthening the factory will not be completed due to the dependence on more than one responsible authority ${ }^{31}$.

To this end, it was decided that as a first step 180 workbenches would be ordered from Loda Factory in order to manufacture 100-150 rifles a day in the rifle factory. Upon the demand for a project of a rifle factory capable of manufacturing 500 rifles a day, an expert engineer would be commissioned in order to carry out examinations at Loda Factory with best workbenches and equipment. Finally, upon the project to be prepared by him would be deemed essential.

The project prepared by Mr. Behstein, the director ${ }^{32}$ of the Loda Factory, who were then in Istanbul, was presented to the authorities. His report was examined in detail and deemed feasible. However, it was understood that rifle manufacture was not an easy process and there was a long time between the arrival of workbenches supplied from anywhere and their proper assembly, and the beginning of the rifle production, since there was a need for a duration, probably months, for the supply or manufacture of the assembly devices of the workbenches, as well as workman and examiner rulers ${ }^{33}$.

${ }^{31}$ ATASE, BDH-2346-40-001-23.

32 'Behstein' mentioned previously as the deputy director of the factory might have been promoted to the post of director of the same factory.

${ }^{33}$ ATASE, BDH-2346-40-001-24. 
We do not exactly know the results of the Behstein's plan. However, it gives substantial evidence about the process of establishment of a factory based on German experience in the beginning of WWI.

In conclusion, military reform attempts in weapons technology and transfer of technical know-how from European countries and Germany in particular seem to bring about two consequences of a controversial nature. First of all, they initiated a pattern of technological dependence on Germany, when we estimate the employment of an increasing number of technicians in all sectors of military technology. On the other hand it could be evaluated from an optimistic perspective. The interaction with German engineers and technologies paved the way for the development of a fertile platform for the rise and training of prospective native officers, technicians and experts equipped with the up-todate knowledge in military sciences and technologies. The case of Behstein Factory shows that, the construction, reconstruction, repair of domestic weapons factories or conversion of the old factories into the new modern ones capable of manufacturing more rifles within a shorter time was the main objective of the Ottoman military authorities. However, this was not an easy process suffered from many drawbacks such as the difficulty in the adaptation of new factory designs, importing/transfer of new equipment, machines and spare parts as well as the coordination and financing of all this process in a time WWI was underway. Yet, the lack of the experienced engineers, technicians and shortly human sources constituted probably the greatest problem for the Ottomans.

We hope that this modest article will contribute to the prospective studies concerning the dichotomy of modernization and dependency, the methods of the transfer of military technologies and know-how and finally and more specifically Ottoman-German military and technological interactions.

\section{BIBLIOGRAPHIA}

\section{ARGHIVAL SOURGES}

Genel Kurmay Askeri Tarih ve Stratejik Etüt Başkanlığ Arşivi (General Staff, Military History and Strategic Studies Presidency Archives, ATASE)

ATASE, BDH-2093-23-001-02

ATASE, BDH-2093-23-001-03

ATASE, BDH-2093-23-001-04

ATASE, BDH-2093-23-001-79

ATASE, BDH-2093-23-001-82

ATASE, BDH-2093-23-001-118

ATASE, BDH-2098-2-001 
ATASE, BDH-2098-2-001-02

ATASE, BDH-2103-15-001-41

ATASE, BDH-2103-16-001

ATASE, BDH-2120-41-004

ATASE, BDH-2120-42-001-025

ATASE, BDH-2114-20-001-12

ATASE, BDH-2133-1-001

ATASE, BDH-2346-39-001-08

ATASE, BDH-2346-39-001-35

ATASE, BDH-2346-39-001-57

ATASE, BDH-2346-40-001-13

ATASE, BDH-2346-40-001-14

ATASE, BDH-2346-40-001-15

ATASE, BDH-2346-40-001-16

ATASE, BDH-2346-40-001-22

ATASE, BDH-2346-40-001-23

ATASE, BDH-2346-40-001-24

\section{SEGONDARY SOURGES}

Beşirli, Mehmet, 'Birinci Dünya Savaşı Öncesinde Türk Ordusunun Top Mühimmatı Alımında Pazar Mücadelesi: Alman Friedrich Krupp Firması ve Rakipleri (Struggle for the Market of Turkish Army's Purchase of Cannon Ammunitions during the Pre-WWI Period: German Friedrich Krupp Company and Its Rivals)', Selçuk Üniversitesi Türkiyat Araştırmalan Merkezi Dergisi, no. 15, Konya: Spring 2004, pp. 169-203.

'II. Abdülhamid Döneminde Osmanlı Ordusunda Alman Silahları (German Weapons in the Ottoman Army in the Reign of Abdulhamid II)', Erciyes Üniversitesi Sosyal Bilimler Enstitiisï Dergisi, no. 16, Year 2004/1, pp. 121-139.

Beydilli, Beydilli, Türk Bilim ve Matbaacılı Tarihinde Mühendishane, Mühendishane Matbaası ve Kütüphanesi 1776-1826, Eren, İstanbul, 1995.

Durgun, Bülent, 'Alman Islah Heyetleri ve Bischoff’un Balkan Harbinde Osmanlı Ordusu'nun Ulaştırması Hakkında Değerlendirmeleri (The German Military Missions in Turkey and Evaluations of the Inspector Bischoff on the Transportation Issues in the Ottoman Army', Türk Dïnyasi Incelemeleri Dergisi / Journal of Turkish World Studies, XII/2 (Winter 2012), pp.101-120.

Fuhrman, Malte, 'Visions of Germany in Turkey: Legitimizing German Imperialist Penetrations of the Ottoman Empire', Free University, Berlin, (undated), pp. 1-20. 
Illich, Niles Stefan, 'German Imperialism in the Ottoman Empire: A Comparative Study', PhD. Dissertation in History, Texas A\&M University, 2007.

İhsanoğlu, Ekmeleddin, "Ottoman Science in the Classical Period and Early Contacts with European Science and Technology", Transfer of Modern Science and Technology to the Muslim World, IRCICA, İstanbul, 1992, s. 1-49.

Mete, Ali Serdar, Osmanl Imparatorluğundan Türkiye Cumhuriyetine Türk Ordusunda Mavzer Tüfekleri (Mauser Rifles in the Turkish Army from the Ottoman Empire to the Turkish Republic), MA Thesis at the Institute of Ataturk's Principles and History of Turkish Renovation, Yeditepe University, 2012.

Ortaylı, İlber, Osmanl İmparatorluğu'nda Alman Nïfuzu (German Influence in the Ottoman Empire), Timaş, İstanbul, 2012.

Öncü, Edip, 'The Beginnings of Ottoman-German Partnership: Diplomatic and Military Relations Between Germany and the Ottoman Empire Before the First World War', MA Thesis in History, Bilken University, Ankara, 2003.

Shaw, Stanford, Between Old and Newe, Ottoman Empire under Selim III (1789-1807), (CambridgeMassachusetts, 1971).

Türk, Fahri, Türkiye ile Almanya Arasindaki Silah Ticareti 1871-1914 (Weapons Trade between Turkey and Germany 1871-1914), IQ Kültür Sanat Yayıncılık, Istanbul, 2012.

Wallach, Jehuda L., Bir Askeri Yardmmn Anatomisi: Türkiye'de Prusya-Alman Askeri Heyetleri 1835-1919 (An Anatomy of an Aid: Prussian-German Military Committees 1835-1919), Translated by Fahri Çeliker, Genelkurmay Basımevi, 2nd Issue, Ankara, 1985.

Yllmaz, Veli, 1'inci Dünya Harbi'nde Türk-Alman İttifakı ve Askeri Yardmlar (Turkish-German Alliance in the WWI and Military Aids), Cem Ofset, İstanbul, 1993.

Yorulmaz, Naci, 'Ottoman Empire and Germany (1871-1908): Military-economic Relationship, Trades Activities of German Armament Industry in the Ottoman Market', Frei University, Berlin, Undated. http://www.turkishnews.com/en/content/wpcontent/uploads/2009/11/ OttomanEmpireGermany 18711908.pdf (12.02.2014), pp. 1-19.

, Arming the Sultan: German Arms Trade and Personal Diplomacy in the Ottoman Empire Before World War I, I.B. Tauris, London\&New York, 2014.

Zorlu, Tuncay. Innovation and Empire in Turkey: Sultan Selim III and Modernisation of the Ottoman Navy, IB Tauris, London\&New York, (2nd edition), 2011. 
